Article

\title{
Connecting Main-Group Metals (Al, Ga, In) and Tungsten(0) Carbonyls via the $\mathrm{N}_{2} \mathrm{~S}_{2}$ Metallo-Ligand Strategy
}

\author{
Xuemei Yang, Allen Lunsford and Marcetta Y. Darensbourg *D \\ Department of Chemistry, Texas A\&M University, 3255 TAMU, College Station, TX 77843, USA; \\ xuemeiyang@tamu.edu (X.Y.); allen.lunsford@intel.com (A.L.) \\ * Correspondence: marcetta@chem.tamu.edu; Tel.: +1-979-845-0158
}

Received: 30 July 2019; Accepted: 5 September 2019; Published: 13 September 2019

\begin{abstract}
Tetradentate $\mathrm{N}_{2} \mathrm{~S}_{2}$ ligands (such as bismercaptoethanediazacycloheptane in this study) have seen extensive use in combination with transition metals. Well-oriented $\mathrm{N}_{2} \mathrm{~S}_{2}$ binding sites are ideal for $\mathrm{d}^{8}$ transition metals with square planar preferences, especially $\mathrm{Ni}^{\mathrm{II}}$, but also as a square pyramidal base for those metals with pentacoordinate preferences, such as $[\mathrm{V} \equiv \mathrm{O}]^{2+},[\mathrm{Fe}(\mathrm{NO})]^{2+}$, and $[\mathrm{Co}(\mathrm{NO})]^{2+}$. Further reactivity at the thiolate sulfurs generates diverse bi, tri, and tetra/heterometallic compounds. Few $\mathrm{N}_{2} \mathrm{~S}_{2}$ ligands have been explored to investigate the possibility of binding to main group metals, especially group III $\left(\mathrm{M}^{\mathrm{III}}\right)$ metals, and their utility as synthons for main group/transition metal bimetallic complexes. To open up this area of chemistry, we synthesized three new five-coordinate main group $\mathrm{XMN}_{2} \mathrm{~S}_{2}$ complexes with methyl as the fifth binding ligand for $\mathrm{M}=\mathrm{Al}$, and chloride for $\mathrm{M}=\mathrm{Ga}$ and In. The seven-membered diazacycle, dach, was engaged as a rigid stabilized connector between the terminal thiolate sulfurs. The pentacoordinate $\mathrm{XMN}_{2} \mathrm{~S}_{2}$ complexes were characterized by ${ }^{1} \mathrm{H}-\mathrm{NMR},{ }^{13} \mathrm{C}-\mathrm{NMR},{ }^{+} \mathrm{ESI}-\mathrm{Mass}$ spectra, and $\mathrm{X}$-ray diffraction. Their stabilities and reactivities were probed by adding $\mathrm{Ni}^{\mathrm{II}}$ sources and $\mathrm{W}(\mathrm{CO})_{5}(\mathrm{THF})$. The former replaces the main group metals in all cases in the $\mathrm{N}_{2} \mathrm{~S}_{2}$ coordination environment, demonstrating the weak coordinate bonds of $\mathrm{M}^{\mathrm{III}}-\mathrm{N} / \mathrm{S}$. The reaction of $\mathrm{XMN}_{2} \mathrm{~S}_{2}\left(\mathrm{XM}=\mathrm{ClGa}^{\mathrm{III}}\right.$ or $\left.\mathrm{ClIn}{ }^{\mathrm{III}}\right)$ with the labile ligand $\mathrm{W}(0)$ complex $\mathrm{W}(\mathrm{CO})_{5}(\mathrm{THF})$ resulted in $\mathrm{Ga} / \mathrm{In}-\mathrm{W}$ bimetallic complexes with a thiolate S-bridge. The synthesis of $\mathrm{XMN}_{2} \mathrm{~S}_{2}$ complexes provide examples of $\mathrm{M}^{\mathrm{III}}-\mathrm{S}$ coordination, especially $\mathrm{Al}-\mathrm{S}$, which is relatively rare. The bimetallic Ga/In-S-W complex formation indicates that the nucleophilic ability of sulfur is retained in $\mathrm{M}^{\mathrm{III}}-\mathrm{S}-\mathrm{R}$, resulting in the ability of main group $\mathrm{M}^{\mathrm{III}}-\mathrm{N}_{2} \mathrm{~S}_{2}$ complexes to serve as metalloligands.
\end{abstract}

Keywords: $\mathrm{N}_{2} \mathrm{~S}_{2}$ ligand; main Group III metals; gallium tungsten bimetallic

\section{Introduction}

In the early 1960s, Busch and co-workers reported the complexing ability of mercaptamines (NS ligands) for $\mathrm{Ni}^{\mathrm{II}}$ [1]. Since then, various NS ligands have been reported, including those with a contiguous $\mathrm{S}-\mathrm{N}-\mathrm{N}-\mathrm{S}, \mathrm{N}_{2} \mathrm{~S}_{2}$, tetradentate donor set, an arrangement that mimics the $\mathrm{N}_{2} \mathrm{~S}_{2}$ coordination environment rendered by a cysteine-glycine/serine-cysteine tripeptide motif found at three enzyme active sites [2]. Further development has been robust. Of special note is the bimetallic Ni-Ni site in acetyl co-A synthase, ACS, in which $\mathrm{N}_{2} \mathrm{~S}_{2}$ is viewed as a tight Ni-binding site, while the second nickel is labile and catalytically active in the $\mathrm{C}-\mathrm{C}$ coupling reactions required of ACS, as shown in Figure 1 [3]. 


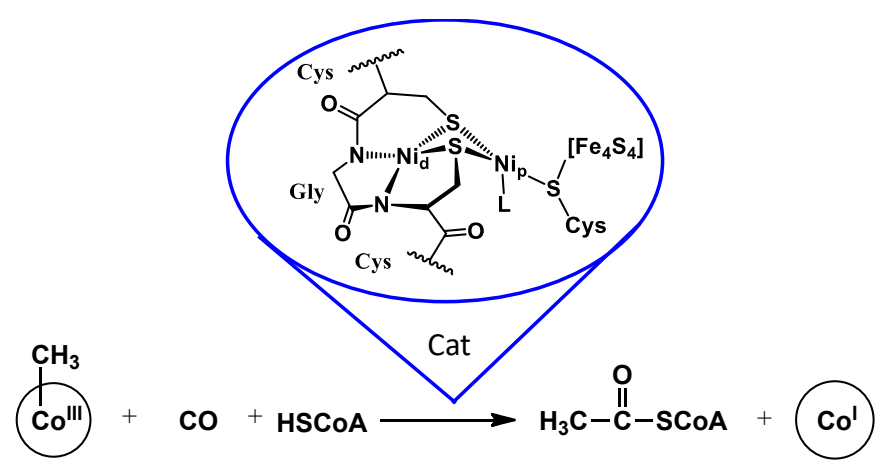

Figure 1. Structure and function of the dinickel enzyme active site of acetyl co-A synthase [3].

We developed $\mathrm{NiN}_{2} \mathrm{~S}_{2}$ complexes as metallodithiolate ligands, especially engaging diazamesocycles $\mathrm{N}_{2} \mathrm{C}_{6} \mathrm{H}_{8}$ (daco), $\mathrm{N}_{2} \mathrm{C}_{5} \mathrm{H}_{10}$ (dach), and $\mathrm{N}_{2} \mathrm{C}_{4} \mathrm{H}_{8}$ (dach*) as stabilizing units in $\mathrm{N}$ to $\mathrm{N}$ connections [4-6]. Those containing the more flexible "open-chain" ethylene or propylene $\mathrm{N}$ to $\mathrm{N}$ linkers bring more flexibility to the $\mathrm{N}_{2} \mathrm{~S}_{2}$ binding unit, resulting in subtle differences in reactivity and stability properties. The ability to tune the $\mathrm{MN}_{2} \mathrm{~S}_{2}$ ligands by variations of $\mathrm{M}$ has resulted in a range of complexes, such as $\mathrm{V}^{4+}$ in $[\mathrm{V} \equiv \mathrm{O}]^{2+}$, $\mathrm{Fe}^{2+}$ in $\{\mathrm{Fe}(\mathrm{NO})\}^{7}, \mathrm{Ni}^{2+}, \mathrm{Pd}^{2+}, \mathrm{Cu}^{2+}$, and $\mathrm{Zn}^{2+}$ [7]. The ability of the $\mathrm{MN}_{2} \mathrm{~S}_{2}$ metalloligands to serve as monodentate as well as bidentate ligands to a single metal or as bridging bidentate ligands to two metals has led to multiple new compositions and various diverse structural forms [7]. A few of these are illustrated in Figure 2 [7]. However, the chemistry of $\mathrm{N}_{2} \mathrm{~S}_{2}$ derivatives of main group metals remains relatively unexplored, and their ability to serve as aggregation sites for exogeneous metals has until now, to our knowledge, been unreported.

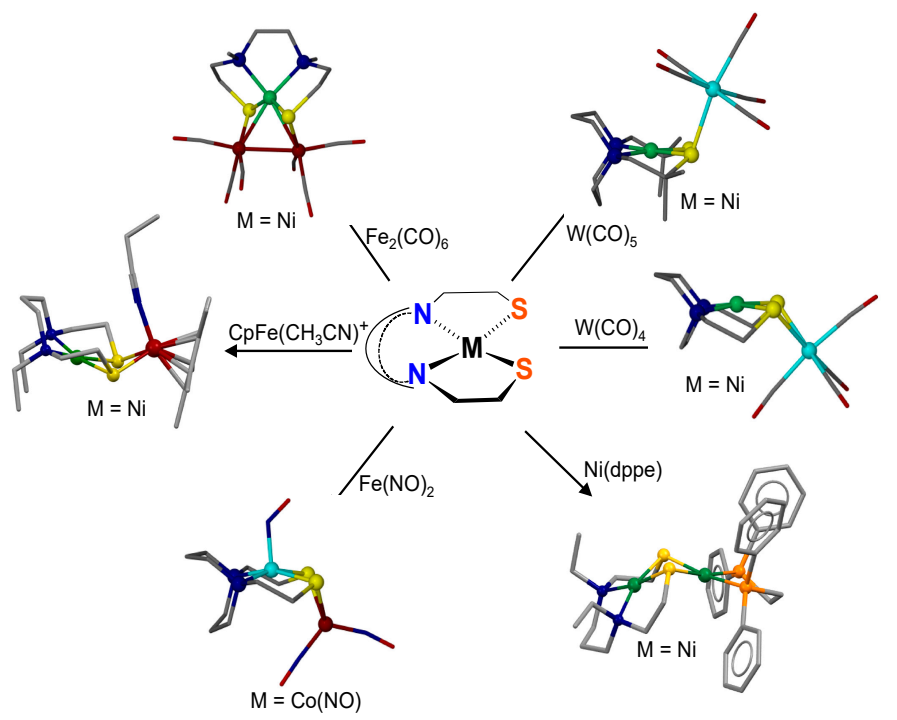

Figure 2. Examples of bi- and trimetallic complexes accessed by connecting the $\mathrm{MN}_{2} \mathrm{~S}_{2}$ metallodithiolate ligand to various transition metal receivers, adapted from [7].

While the expectation that the soft $\mathrm{S}$ will have a poor binding affinity for hard $\mathrm{Al}(\mathrm{III})$ is reasonable, a Cambridge database search located 36 results of $\mathrm{N}_{2} \mathrm{~S}_{2}$ derivatives of aluminum. Most of them are derived from an aluminum (I) precursor [8,9]. The use of abundant aluminum in catalysis is well known, including as catalysts for $\mathrm{CO}_{2}$ /epoxide cycloaddition $[10,11]$, which comprises a tetradentate $\mathrm{N}_{2} \mathrm{O}_{2}$ ligand with an axial $\mathrm{X}$ ligand $(\mathrm{X}=$ alkyl, halogen completing the coordination sphere). In contrast, many more sulfur_coordinated gallium(III) and indium(III) complexes have been reported, owing to the softer core of $\mathrm{Ga}(\mathrm{III}) / \mathrm{In}(\mathrm{III})$ [12-17]. Explorations in those cases have been prompted by the wide use of ${ }^{111} \mathrm{In}$ and ${ }^{67} \mathrm{Ga}$ as radionuclides in PET (Positron Emission Tomography) and SPECT (Single Photon Emission Computed Tomography) [18]. 
In order to extend the coordination chemistry of main group III metals with this versatile ligand motif, we explored the synthesis and characterization of Group III elements, such as $\mathrm{Ga} / \mathrm{In}-\mathrm{Cl}$ or Al-R, bound within the $\mathrm{N}_{2} \mathrm{~S}_{2}$ binding cavity. We probed the availability of the residual $S$ lone pairs to serve as nucleophiles for the binding to exogeneous metals. In particular, heterobimetallics were formed with $\mathrm{W}(\mathrm{CO})_{4 / 5}$, a receiver unit with the $\mathrm{CO}$ reporter unit, which provides a reference point for establishing donor ability of such metalloligands [7].

\section{Results}

\subsection{Synthesis and Characterizations of $\mathrm{XMN}_{2} \mathrm{~S}_{2}$ Complexes}

The $\mathrm{H}_{2}$ bme-dach ( $N, N^{\prime}$-Bis(Mercaptoethyl)-1,4-Diazacycloheptane) was synthesized according to a reported procedure [4]. Under an $\mathrm{N}_{2}$ atmosphere, a solution of $\mathrm{AlMe}_{3}, \mathrm{GaCl}_{3}$, or $\mathrm{InCl}_{3}$ was transferred by a double-ended needle into a solution of $\mathrm{H}_{2}$ bme-dach ligand in a Schlenk flask. White powdery products formed immediately, resulting in a white suspension. After stirring overnight, the solvent was removed under vacuum giving white solids, determined to be the compounds shown in Figure 3 . They were further washed with $\mathrm{Et}_{2} \mathrm{O}$ and pentane, giving a yield of $75-80 \%$.

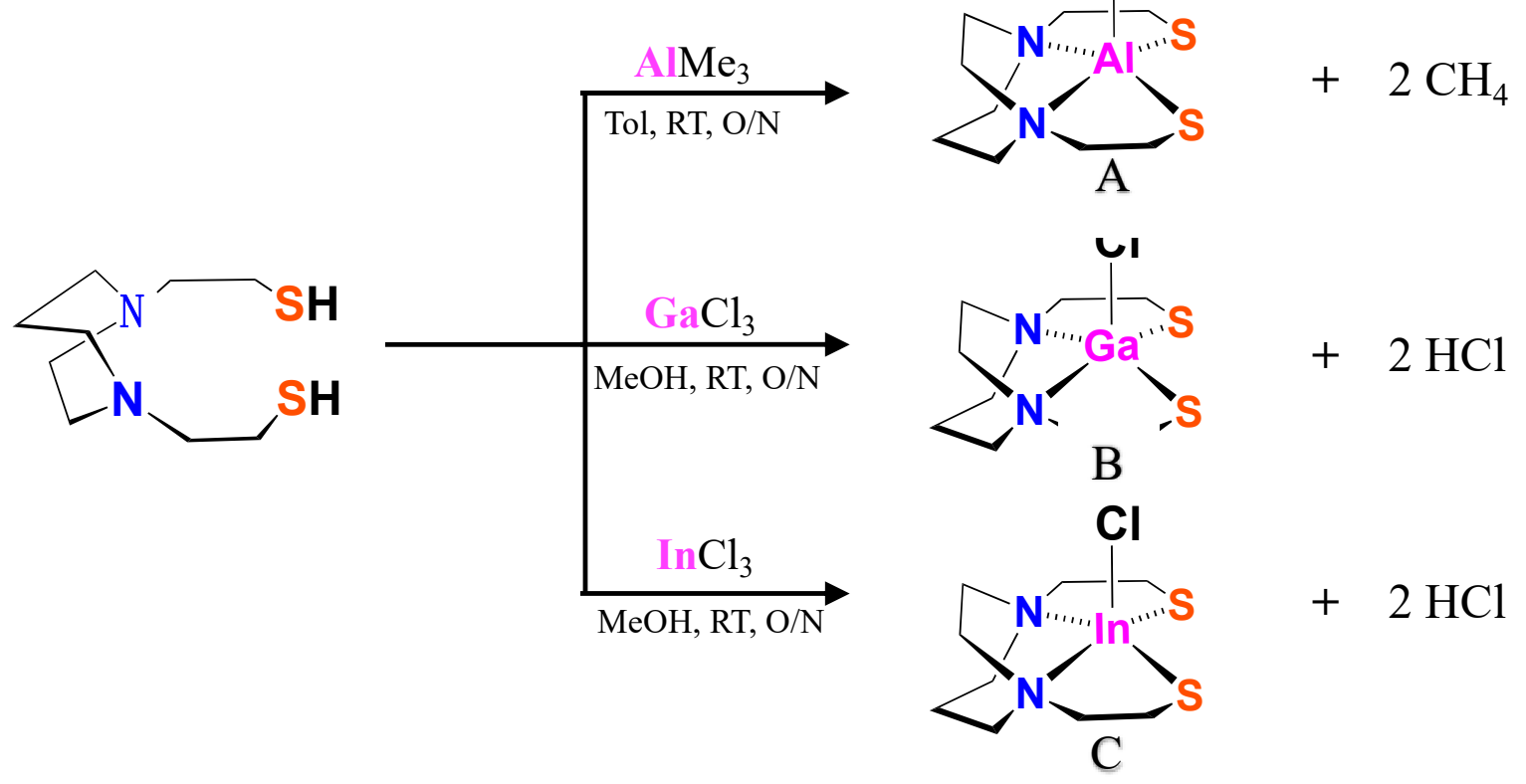

Figure 3. Synthetic routes for $\mathrm{XMN}_{2} \mathrm{~S}_{2}$ complexes; $\mathrm{RT}$ is ca. $22{ }^{\circ} \mathrm{C}$ and $\mathrm{O} / \mathrm{N}$ is ca. $14 \mathrm{~h}$.

The $\mathrm{XMN}_{2} \mathrm{~S}_{2}$ complexes were characterized by XRD, ESI-mass spectra, ${ }^{1} \mathrm{H}-\mathrm{NMR}$ and ${ }^{13} \mathrm{C}-\mathrm{NMR}$. Details are shown in the Supporting Information. The $\mathrm{X}$-ray quality crystals of $\mathbf{A}$ were developed in pyridine solution at $-28^{\circ} \mathrm{C}$. Crystals of $\mathbf{B}$ and $\mathbf{C}$ were obtained by slow evaporation of $\mathrm{Et}_{2} \mathrm{O}$ vapor into a pyridine solution. All crystals were colorless needles. Metric parameters for the molecular structures are given in Figure 4. 


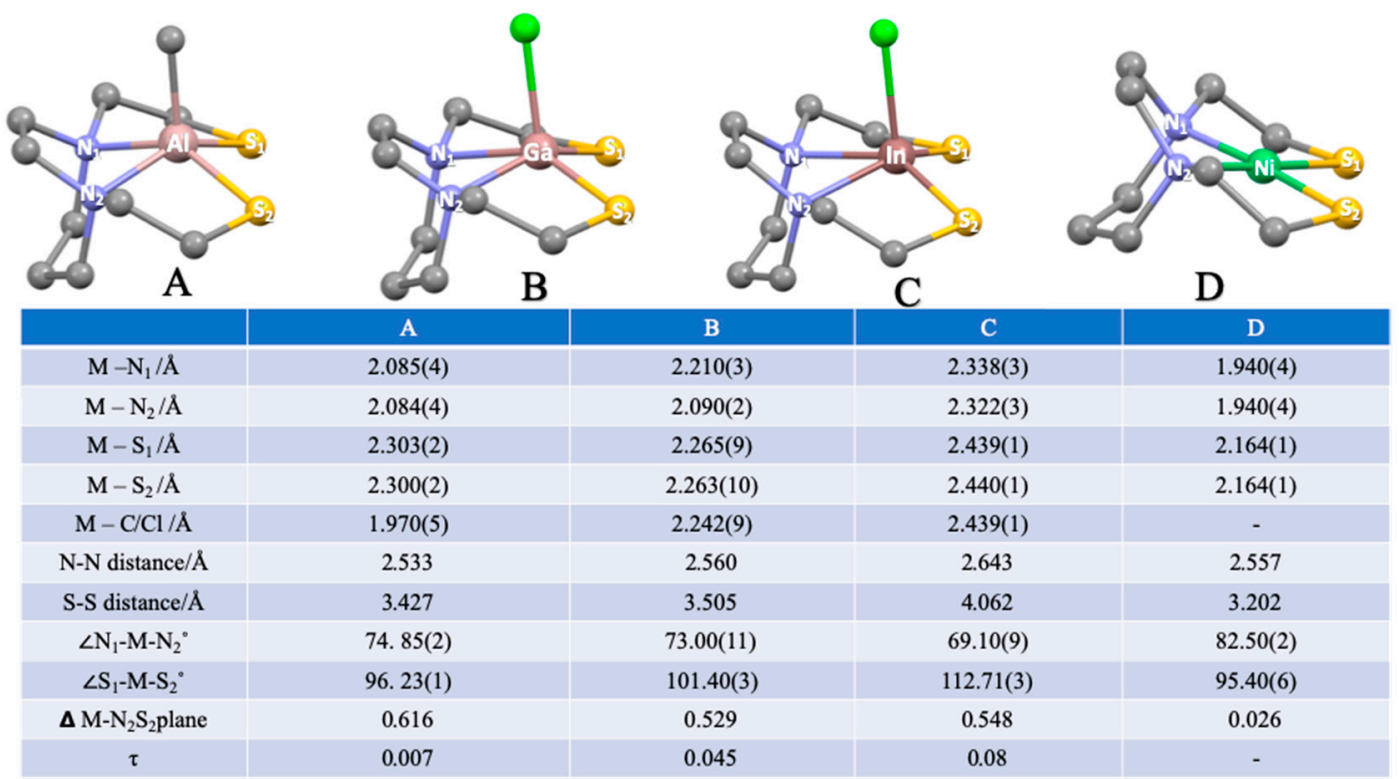

Figure 4. Molecular structures of $\mathrm{XMN}_{2} \mathrm{~S}_{2}$ complexes from XRD analysis with selected metric data.

The geometries of $\mathrm{XMN}_{2} \mathrm{~S}_{2}(\mathrm{M}=\mathrm{Al}, \mathrm{Ga}$, and In) were similar, as the ideality of the square pyramidal structures is indicated by small $\tau$ values (near 0) [19]. The displacements of $M$ from the best $\mathrm{N}_{2} \mathrm{~S}_{2}$ planes showed aluminum to be the most out of plane, $\Delta=0.616 \AA$, while Ga and In showed displacements in the range of $0.53-0.55 \AA$. These displacements are likewise seen in some pentacoordinate transition metal complexes, such as $\mathrm{MN}_{2} \mathrm{~S}_{2}$, where $\mathrm{M}=[\mathrm{Co}(\mathrm{NO})]^{2+}(0.31 \AA),[\mathrm{Fe}(\mathrm{NO})]^{2+}(0.55 \AA)$, and $[\mathrm{V} \equiv \mathrm{O}]^{2+}$ $(0.652 \AA)[20,21]$. In all cases of $\mathbf{A}, \mathbf{B}$, and $\mathbf{C}$, the two-carbon linker within the diazacycloheptane ring is on the same side as the $\mathrm{M}^{\mathrm{III}}-\mathrm{X}$ bond vector. This means that the $\mathrm{MN}_{2} \mathrm{C}_{3}$ cyclohexane-type ring in the chair configuration is oriented "underneath" the $\mathrm{N}_{2} \mathrm{~S}_{2}$ base of the square pyramidal $\mathrm{X}-\mathrm{MN}_{2} \mathrm{~S}_{2}$ structure. We saw no evidence of fluxionality in the solution.

Different from Ga and In, which are largely located on the midpoint line in the center of the $\mathrm{N}_{2} \mathrm{~S}_{2}$ unit, $\mathrm{Al}$ showed a slight dissymmetry in its location, shifted towards the nitrogen atoms (Al-N is around $2.1 \AA$ ) and away from the sulfur atoms (Al-S is around 2.3 $\AA$ ). This suggests a stronger electrostatic interaction to $\mathrm{N}$ from the $\mathrm{Al}^{\mathrm{III}}$. Table $\mathrm{S} 5$ lists the comparative ratios of the $\mathrm{M}-\mathrm{N} / \mathrm{M}-\mathrm{S}$ distances that emphasize the similarity of $\mathrm{Ga}$ and In and their greater affinity for sulfur. From $\mathrm{Al}, \mathrm{Ga}$, to In, the angles of $\angle \mathrm{N}-\mathrm{M}-\mathrm{N}$ decreased with a concomitant increase in $\angle \mathrm{S}-\mathrm{M}-\mathrm{S}$.

\subsection{Reactions of $\mathrm{XMN}_{2} \mathrm{~S}_{2}$ with $\mathrm{Ni}(\mathrm{II})$ Sources}

The optimal sized $\mathrm{N}_{2} \mathrm{~S}_{2}$ cavity of the bme-dach and analogous ligands, as well as the electronic structure preference of $\mathrm{d}^{8} \mathrm{Ni}^{\mathrm{II}}$, leads to a well-known library of square planar $\mathrm{NiN}_{2} \mathrm{~S}_{2}$ complexes [7]. Thus, we probed the possibility of $\mathrm{Ni}^{\mathrm{II}}$ replacement of the Group III metal ions in the $\mathrm{XMN}_{2} \mathrm{~S}_{2}$ complexes. Such metal exchange studies were not easily performed in the transition metal complexes, as aggregation at the sulfur elements was prominent.

The addition of $\mathrm{NiCl}_{2}$ or $\mathrm{Ni}\left(\mathrm{BF}_{4}\right)_{2}$ to $\mathrm{XM}^{\mathrm{III}} \mathrm{N}_{2} \mathrm{~S}_{2}$ complexes resulted in the formation of $\mathrm{NiN}_{2} \mathrm{~S}_{2}$ with $\mathrm{M}^{\mathrm{III}}$ replaced by $\mathrm{Ni}^{\mathrm{II}}$, concomitant with a color change from colorless to dark maroon, illustrated in Figure 5. The resulting maroon product gave a yield of $75-80 \%$ and was confirmed as the known $\mathrm{NiN}_{2} \mathrm{~S}_{2}$ complex by mass spectroscopy (Figure S12) and X-ray structure analyses. To determine whether the XM ${ }^{\mathrm{III}}$ unit might remain in the $\mathrm{N}_{2} \mathrm{~S}_{2}$ cavity with the attachment of Ni(diphos) to the nucleophilic sulfurs of $X M^{\mathrm{III}} \mathrm{N}_{2} \mathrm{~S}_{2}$, we added the (diphos) $\mathrm{NiCl}_{2}$ complex to a solution of $X \mathrm{XM}^{\mathrm{III}} \mathrm{N}_{2} \mathrm{~S}_{2}$. The product of that reaction was determined to be the well-known dinickel complex derived from two (diphos) $\mathrm{NiCl}_{2}$ complexes with $\mathrm{Ni}^{\mathrm{II}}$ moving into the tight binding site, replacing $\mathrm{XM}^{\mathrm{III}}$, and the second nickel holding on to the diphos ligand, Figure 5. The stability of the $\mathrm{NiN}_{2} \mathrm{~S}_{2}$ complex relative to $\mathrm{XM}^{\mathrm{III}} \mathrm{N}_{2} \mathrm{~S}_{2}$ was confirmed. 


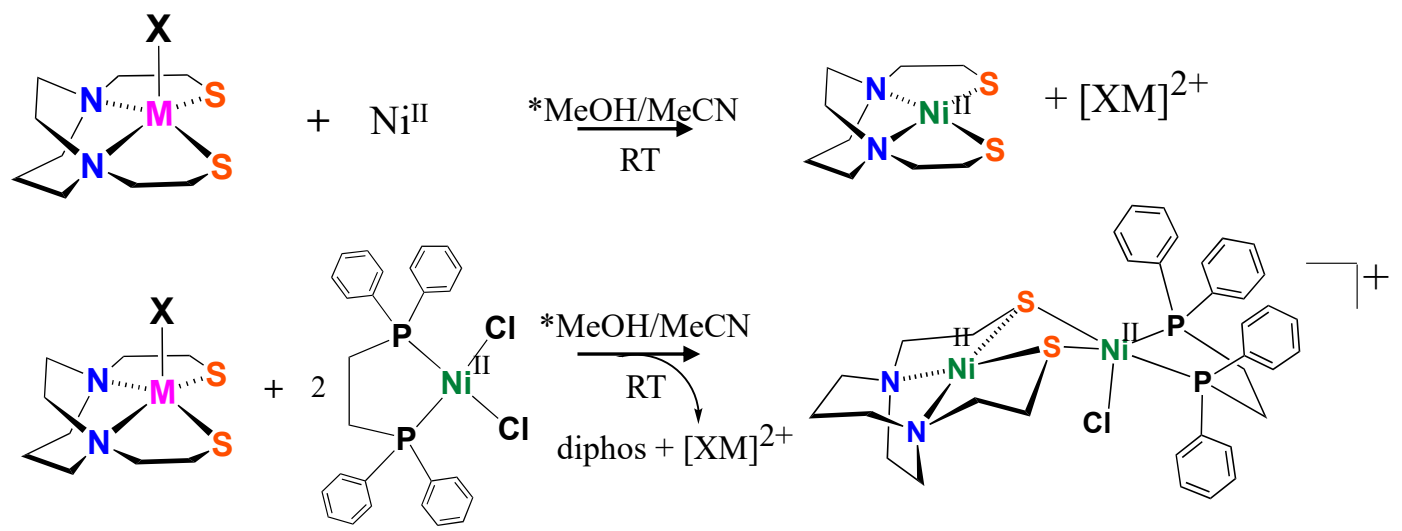

Figure 5. Reactions of $\mathrm{XMN}_{2} \mathrm{~S}_{2}$ with $\mathrm{Ni}^{\mathrm{II}}$ salts and (diphos) $\mathrm{NiCl}_{2}$. ${ }^{*} \mathrm{Pure} \mathrm{MeOH}$, or $\mathrm{MeCN}$, or a mixture of $\mathrm{MeOH} / \mathrm{MeCN}(1: 1)$ resulted in the same products.

\subsection{Nucleophilicity of $S$ Lone Pairs on $\mathrm{XMN}_{2} \mathrm{~S}_{2}$ Towards the Soft Receiver $\mathrm{W}(\mathrm{CO})_{5}$}

The stability and electronic reporting capability of tungsten carbonyls have proven useful to rank the donor ability of various $\mathrm{MN}_{2} \mathrm{~S}_{2}$ metalloligands. The labile ligand synthons $\mathrm{W}(\mathrm{CO})_{5}(\mathrm{solv})$ and $\mathrm{W}(\mathrm{CO})_{4}(\text { solv })_{2}$ were generated by appropriate methods [22,23]. Carbon monoxide was lost in solutions of $\mathrm{W}(\mathrm{CO})_{6}$ in THF under UV light, after which the golden yellow solution showed the $v(\mathrm{CO}) \mathrm{C}_{4 \mathrm{v}}$ pattern typical of $\mathrm{W}(\mathrm{CO})_{5}(\mathrm{THF})$ and was transferred via cannula to a solution of $\mathrm{XMN}_{2} \mathrm{~S}_{2}$ $(\mathrm{XM}=\mathrm{ClGa} / \mathrm{ClIn})$. Over the course of several hours at room temperature, with no further photolysis, the color changed to brown-orange. As shown in the overlaid spectra in Figure 6, the shift in $v(\mathrm{CO})$ was not large, indicating the donor ability of THF and monodentate $\mathrm{XMN}_{2} \mathrm{~S}_{2}$ toward $\mathrm{W}(\mathrm{CO})_{5}$ is similar and weak. In contrast, $\mathrm{NiN}_{2} \mathrm{~S}_{2}$ reacted with $\mathrm{W}(\mathrm{CO})_{5}(\mathrm{THF})$, producing a much greater change in $v(\mathrm{CO})$ of $2062(\mathrm{w}), 1922(\mathrm{~s})$, and $1884(\mathrm{~m})$ [23]. The MeAlN $\mathrm{S}_{2}$ metalloligand itself is not stable under UV light and gave products of degradation in the presence of $\mathrm{W}(\mathrm{CO})_{5}(\mathrm{THF})$.

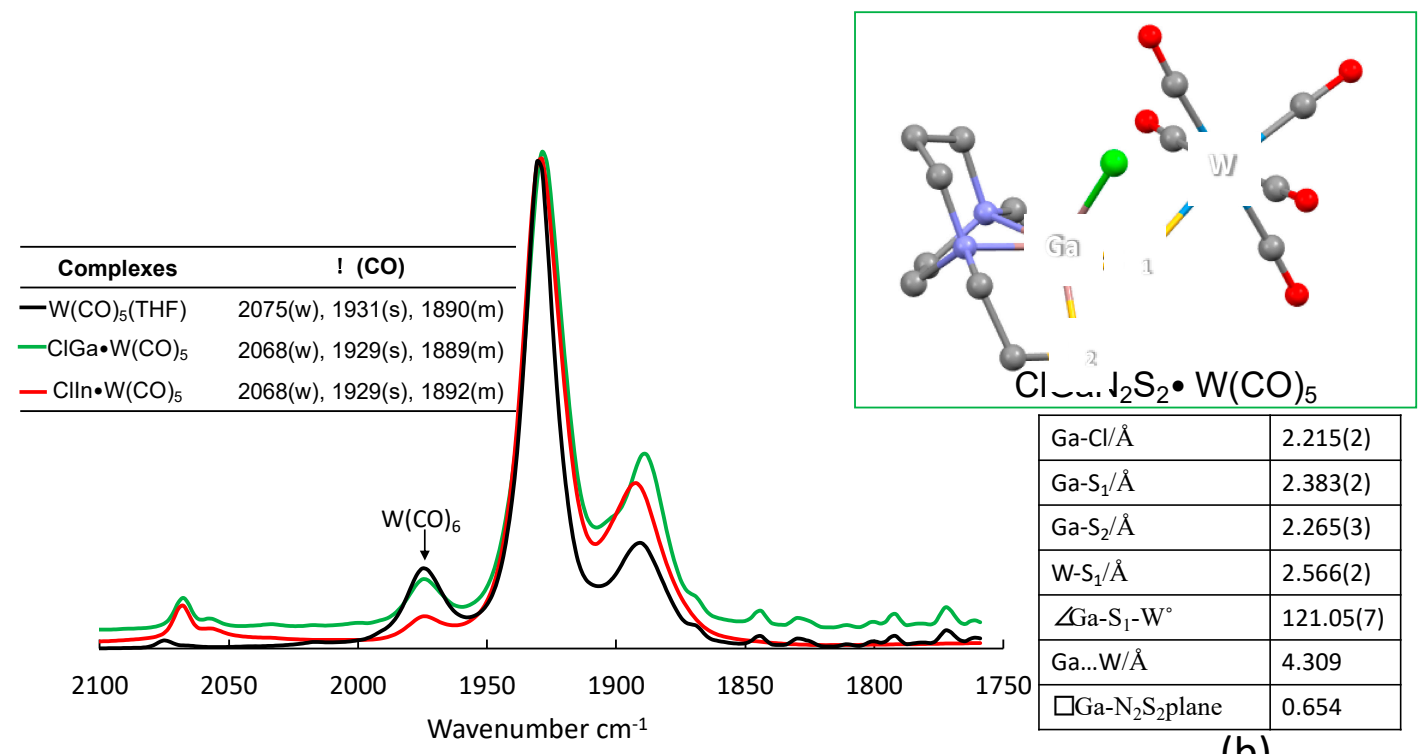

(a)

(b)

Figure 6. (a) IR spectra in $v(\mathrm{CO})$ region of products from reactions of $\mathrm{W}(\mathrm{CO})_{5}(\mathrm{THF})$ with $\mathrm{XMN}_{2} \mathrm{~S}_{2}$; (b) XRD determined molecular structure of $\mathrm{ClGaN}_{2} \mathrm{~S}_{2} \cdot \mathrm{W}(\mathrm{CO})_{5}$ with selected metric data.

Orange sheet crystals of $\mathrm{ClGaN}_{2} \mathrm{~S}_{2} \cdot \mathrm{W}(\mathrm{CO})_{5}$ were obtained from THF solution by hexane layering. The X-ray diffraction study showed that the geometry and metric parameters were largely the same in the free and S-bound monodentate complexes. The Ga- $\mathrm{S}_{1}$ bridge bond was elongated compared 
with the $\mathrm{ClGaN}_{2} \mathrm{~S}_{2}$ structure. The $\mathrm{N}_{2} \mathrm{~S}_{2}$ "plane" was quite distorted, giving the $\mathrm{ClGaN}_{2} \mathrm{~S}_{2}$ a geometry between square pyramidal and trigonal bipyramidal with the $\tau$ value 0.50, as shown in Figure S18 [19]. Gallium(III) was significantly more displaced from the $\mathrm{N}_{2} \mathrm{~S}_{2}$ "plane", giving a deviation of over $0.1 \AA$ (0.529 $\AA$ in $\mathrm{ClGaN}_{2} \mathrm{~S}_{2}$ to $0.654 \AA$ in $\left.\mathrm{ClGaN}_{2} \mathrm{~S}_{2} \cdot \mathrm{W}(\mathrm{CO})_{5}\right)$. The distance between $\mathrm{Ga}$ and $\mathrm{W}$ was $4.309 \AA$.

On further exposing $\mathrm{ClGaN}_{2} \mathrm{~S}_{2} \cdot \mathrm{W}(\mathrm{CO})_{5}$ to UV light, a second $\mathrm{CO}$ was lost, yielding $\mathrm{ClGaN}_{2} \mathrm{~S}_{2} \cdot \mathrm{W}(\mathrm{CO})_{4}$. The $v(\mathrm{CO})$ IR spectrum displays a four-band pattern typical of $\mathrm{C}_{2 \mathrm{v}}$ metal carbonyl derivatives; the values are $2004(\mathrm{w}), 1929(\mathrm{~m}), 1890(\mathrm{~m})$, and $1846(\mathrm{~m}) \mathrm{cm}^{-1}$ with the color changing to light orange, Figure 7. Similar to the $\mathrm{ClGaN}_{2} \mathrm{~S}_{2} \cdot \mathrm{W}(\mathrm{CO})_{5}$ complex, the $\mathrm{ClInN}_{2} \mathrm{~S}_{2} \cdot \mathrm{W}(\mathrm{CO})_{5}$ converted to $\mathrm{ClInN}_{2} \mathrm{~S}_{2} \cdot \mathrm{W}(\mathrm{CO})_{4}$ under light, giving $v(C O)$ values of $2007(\mathrm{w}), 1929(\mathrm{~m}), 1894(\mathrm{~m})$, and $1850(\mathrm{~m}) \mathrm{cm}^{-1}$, as shown in Figure S17. The final product was confirmed by ${ }^{-}$ESI-Mass, and details are given in the Supplementary Materials. The experimental results indicate that the thiolate sulfurs in the $\mathrm{XMN}_{2} \mathrm{~S}_{2}$ complexes are still sufficiently active to bind another metal. However, the binding ability is weak. The latter statement was confirmed by the reversibility of the $\mathrm{CO}$ loss. On bubbling $\mathrm{CO}$ through the solution of $\mathrm{ClGaN}_{2} \mathrm{~S}_{2} \cdot \mathrm{W}(\mathrm{CO})_{4}$, the pentacarbonyl was readily reclaimed.

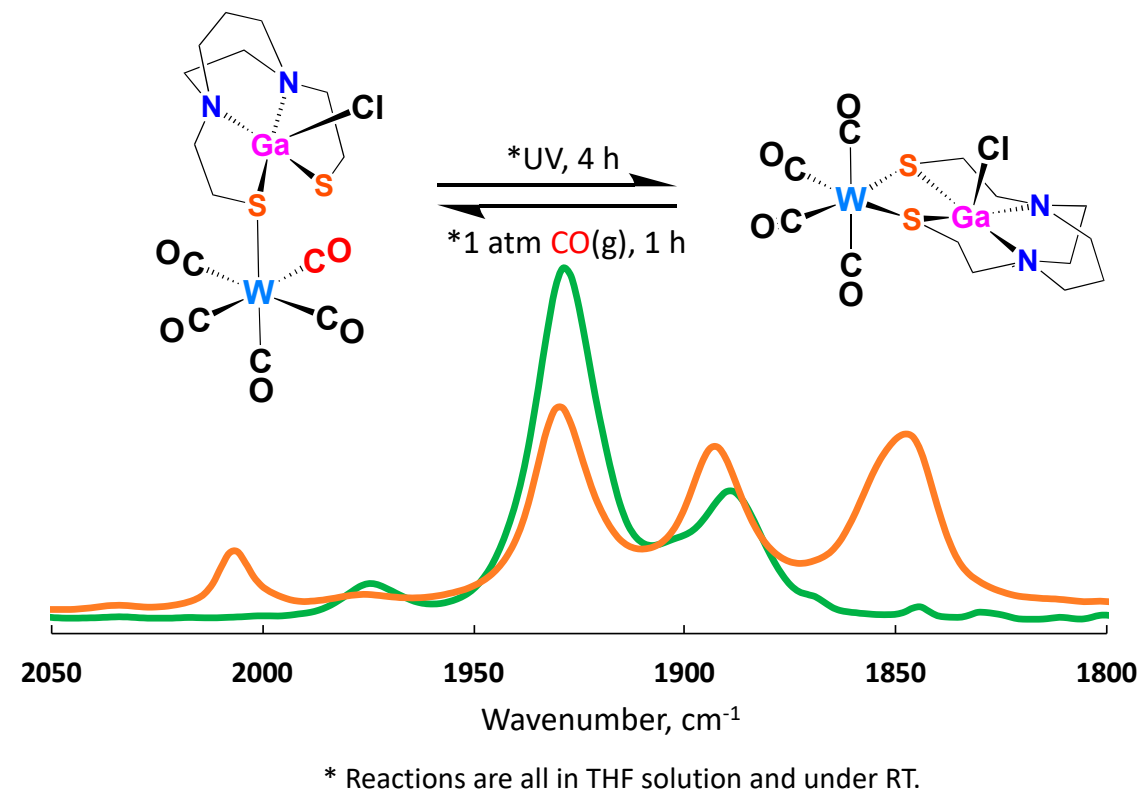

Figure 7. Reactions of $\mathrm{ClGaN}_{2} \mathrm{~S}_{2} \cdot \mathrm{W}(\mathrm{CO})_{5}$ and $\mathrm{ClGaN}_{2} \mathrm{~S}_{2} \cdot \mathrm{W}(\mathrm{CO})_{4}$ under UV light irradiation. $\mathrm{ClGaN}_{2} \mathrm{~S}_{2} \cdot \mathrm{W}(\mathrm{CO})_{5}$ converted to $\mathrm{ClGaN}_{2} \mathrm{~S}_{2} \cdot \mathrm{W}(\mathrm{CO})_{4}$ and, reversibility established by bubbling $\mathrm{CO}(\mathrm{g})$ to $\mathrm{ClGaN}_{2} \mathrm{~S}_{2} \cdot \mathrm{W}(\mathrm{CO})_{4}$ resulting in the reformation of $\mathrm{ClGaN}_{2} \mathrm{~S}_{2} \cdot \mathrm{W}(\mathrm{CO})_{5}$. The green line is for $\mathrm{ClGaN}_{2} \mathrm{~S}_{2} \cdot \mathrm{W}(\mathrm{CO})_{5}$ and the orange line is for $\mathrm{ClGaN}_{2} \mathrm{~S}_{2} \cdot \mathrm{W}(\mathrm{CO})_{4}$.

\section{Materials and Methods}

All reagents and solvents were obtained from commercial sources. All solvents were purified and dried by an MBRAUN Manual Solvent Purification System (MBRAUN, NH, USA) packed with Alcoa F200 activated alumina desiccant. All reactions and operations were carried out on a double manifold Schlenk vacuum line or in a glovebox under a $\mathrm{N}_{2}$ or Ar atmosphere.

Solution infrared spectra were recorded on a Bruker Tensor 37 Fourier transform IR (FTIR) spectrometer (Billerica, MA, USA) using a $\mathrm{CaF}_{2}$ cell with a $0.2 \mathrm{~mm}$ path length. Both High Resolution and Low Resolution Mass spectrometry (Thermo Fisher Q Exactive Mass Spectrometer, ESI-MS, (IET, IL, USA) were performed in the Laboratory for Biological Mass Spectrometry at Texas A\&M University. Data collections for X-ray structure-determination were carried out using Bruker APEX2 (Billerica, MA, USA) or Venture with a graphite monochromated radiation source $(\lambda=0.71073 \AA)$. All crystals were coated in paraffin oil and mounted on a nylon loop and placed under streaming $\mathrm{N}_{2}$ (110/150K). The structures were solved by direct methods (SHELXS-97) and refined by standard Fourier techniques against $\mathrm{F}$ square with a full-matrix least-squares algorithm using SHELXL-97 
and the WinGX (1.80.05) software package (University Of Glasgow, Scotland, UK). Hydrogen atoms were placed in calculated positions and refined with a riding model. Graphical representations were prepared with ORTEP-III. Crystallographic data (including structure factors) have been deposited with the Cambridge Crystallographic Data Centre as supplementary publication nos. 1943010-1943013.

\subsection{Synthesis of $X M N_{2} S_{2}$}

MeAlN $\mathrm{S}_{2}$ : The $\mathrm{H}_{2}$ bme-dach ligand $(0.22 \mathrm{~g}, 1.0 \mathrm{mmol})$ was added to a $125 \mathrm{~mL}$ Schlenk flask by pipet in an inert atmosphere glove box and dissolved in ca. $10 \mathrm{~mL}$ toluene. A pentane solution of $\mathrm{AlMe}_{3}(1 \mathrm{M}$ in pentane, $1 \mathrm{~mL}, 1 \mathrm{mmol})$ was added dropwise to the ligand solution. After reacting overnight at room temperature, the resulting powdery white solution was filtered, and solvent was removed under vacuum. The white solid was washed with $\mathrm{Et}_{2} \mathrm{O}$ and pentane, giving a $\sim 75 \%$ yield. Proton NMR spectral values $\left(300 \mathrm{MHz}, 293 \mathrm{~K}\right.$, pyridine- $\left.\mathrm{d}_{5}\right)$ were as follows: $\delta(\mathrm{ppm})=4.98(\mathrm{~s}, 8 \mathrm{H}$, $\left.\mathrm{N}_{2} \mathrm{~S}_{2}\right)$ 2.63(q, 2H, $\left.\mathrm{N}_{2} \mathrm{~S}_{2}\right), 2.61\left(\mathrm{q}, 8 \mathrm{H}, \mathrm{N}_{2} \mathrm{~S}_{2}\right), 1.70\left(\mathrm{q}, 2 \mathrm{H}, \mathrm{N}_{2} \mathrm{~S}_{2}\right), 0.10(\mathrm{~s}, 1 \mathrm{H}, \mathrm{Me}) .{ }^{13} \mathrm{C}$ NMR $(300 \mathrm{MHz}, 293$ $\mathrm{K}$, pyridine- $\left.\mathrm{d}_{5}\right): \delta(\mathrm{ppm})=61.40,55.80,54.39,28.81,23.69,-4.01$. High Resolution ${ }^{+}$ESI-Mass: $[\mathrm{M}+\mathrm{H}]^{+}$ $\left(\mathrm{C}_{10} \mathrm{H}_{22} \mathrm{AlN}_{2} \mathrm{~S}_{2}\right)$ Calculated 261.1040 (Most Abundant Isotopic Mass); Found: 261.1033. The detailed isotope abundance is shown in Figure $\mathrm{S} 4$.

$\mathrm{ClGaN}_{2} \mathrm{~S}_{2}$ : Similar to MeAlN $\mathrm{S}_{2}, \mathrm{ClGaN}_{2} \mathrm{~S}_{2}$ was derived from a MeOH solution of $\mathrm{GaCl}_{3}(0.176 \mathrm{~g}$, $1.0 \mathrm{mmol})$ and $\mathrm{H}_{2}$ bme-dach $(0.22 \mathrm{~g}, 1.0 \mathrm{mmol})$ at room temperature. After overnight reaction, the solvent was removed from the resulting powdery white suspension under vacuum, and the white solid was washed with $\mathrm{Et}_{2} \mathrm{O}$ and pentane, giving an $\sim 80 \%$ yield. ${ }^{1} \mathrm{H}$ NMR $\left(300 \mathrm{MHz}, 293 \mathrm{~K}\right.$, pyridine- $\left.\mathrm{d}_{5}\right)$ : $\delta(\mathrm{ppm})=5.75\left(\mathrm{~s}, 8 \mathrm{H}, \mathrm{N}_{2} \mathrm{~S}_{2}\right), 3.62\left(\mathrm{~s}, 4 \mathrm{H}, \mathrm{N}_{2} \mathrm{~S}_{2}\right), 2.84\left(\mathrm{~s}, 2 \mathrm{H}, \mathrm{N}_{2} \mathrm{~S}_{2}\right), 2.17\left(\mathrm{q}, 2 \mathrm{H}, \mathrm{N}_{2} \mathrm{~S}_{2}\right), 1.27\left(\mathrm{q}, 2 \mathrm{H}, \mathrm{N}_{2} \mathrm{~S}_{2}\right)$. ${ }^{13} \mathrm{C}$ NMR $\left(300 \mathrm{MHz}, 293 \mathrm{~K}\right.$, pyridine- $\left.\mathrm{d}_{5}\right): \delta(\mathrm{ppm})=55.96,51.54,48.71,24.62,22.18$. High Resolution ${ }^{+}$ESI-Mass: $[\mathrm{M}-\mathrm{Cl}]^{+}\left(\mathrm{C}_{9} \mathrm{H}_{18} \mathrm{GaN}_{2} \mathrm{~S}_{2}\right)$ Calculated 287.0162; Found: 287.0157 (Most Abundant Isotopic Mass). The detailed isotope abundance is shown in Figure $\mathrm{S} 5$.

ClInN $\mathrm{S}_{2}$ : ClInN $\mathrm{S}_{2}$ was synthesized in a similar method to $\mathrm{ClGaN}_{2} \mathrm{~S}_{2}$. A MeOH solution of $\mathrm{InCl}_{3}$ $(0.221 \mathrm{~g}, 1.0 \mathrm{mmol})$ was added dropwise to a $\mathrm{MeOH}$ solution of $\mathrm{H}_{2}$ bme-dach. The powdery suspension was dried, and the white solid was washed with $\mathrm{Et}_{2} \mathrm{O}$ and pentane. The yield was $85 \% .{ }^{1} \mathrm{H}$ NMR $\left(300 \mathrm{MHz}, 293 \mathrm{~K}\right.$, pyridine- $\left.\mathrm{d}_{5}\right): \delta(\mathrm{ppm})=5.75\left(\mathrm{~s}, 8 \mathrm{H}, \mathrm{N}_{2} \mathrm{~S}_{2}\right), 3.62\left(\mathrm{~s}, 4 \mathrm{H}, \mathrm{N}_{2} \mathrm{~S}_{2}\right), 2.84\left(\mathrm{~s}, 2 \mathrm{H}, \mathrm{N}_{2} \mathrm{~S}_{2}\right)$, 2.17(q, $\left.2 \mathrm{H}, \mathrm{N}_{2} \mathrm{~S}_{2}\right), 1.27\left(\mathrm{q}, 2 \mathrm{H}, \mathrm{N}_{2} \mathrm{~S}_{2}\right) .{ }^{13} \mathrm{C}$ NMR $\left(300 \mathrm{MHz}, 293 \mathrm{~K}\right.$, pyridine- $\left.\mathrm{d}_{5}\right): \delta(\mathrm{ppm})=58.28,53.01$, 48.11, 24.23, 22.83. High Resolution ${ }^{+}$ESI-Mass: $[\mathrm{M}-\mathrm{Cl}]^{+}\left(\mathrm{C}_{9} \mathrm{H}_{18} \mathrm{InN}_{2} \mathrm{~S}_{2}\right)$ Calculated 332.9945; Found: 332.9939 (Most Abundant Isotopic Mass). The detailed isotope abundance is shown in Figure S6.

\subsection{Reactions of $\mathrm{XMN}_{2} \mathrm{~S}_{2}$ with $\mathrm{Ni}(\mathrm{II})$}

The white solid of $\mathrm{XMN}_{2} \mathrm{~S}_{2}(0.1 \mathrm{mmol})$ was placed in a $50 \mathrm{~mL}$ flask, and $10 \mathrm{~mL}$ of a MeOH/MeCN (1:1) mixture was added. The green solution of $\mathrm{NiCl}_{2} \cdot 6 \mathrm{H}_{2} \mathrm{O}(0.1 \mathrm{mmol}, 24 \mathrm{mg})$ in $\mathrm{MeOH}$ was then transferred to the $50 \mathrm{~mL}$ flask. The color immediately changed to maroon, which is typical of $\mathrm{NiN}_{2} \mathrm{~S}_{2}$, and this product was confirmed by its $\mathrm{X}$-ray structure. The same product, $\mathrm{NiN}_{2} \mathrm{~S}_{2}$, was also formed by adding $\mathrm{Ni}\left(\mathrm{BF}_{4}\right)_{2}$ using the same method.

Similar to the reaction with the chloride salt of $\mathrm{Ni}^{\mathrm{II}}$, the white solid of $\mathrm{XMN}_{2} \mathrm{~S}_{2}(0.1 \mathrm{mmol})$ was stirred with $10 \mathrm{~mL} \mathrm{MeCN}$ in the $50 \mathrm{~mL}$ round flask. The $\mathrm{NiP}_{2} \mathrm{Cl}_{2}\left(\mathrm{P}_{2}=\right.$ diphos or 1,1'-diphenylphosphinoethane, $0.105 \mathrm{~g}, 0.2 \mathrm{mmol}$ ) was dissolved in $10 \mathrm{~mL} \mathrm{MeCN}$ and transferred to the flask. The resulting dark brown solution was dried in vacuo, giving a dark brown solid. Dark brown needle crystals were formed under $\mathrm{Et}_{2} \mathrm{O}$ diffusion into a concentrated $\mathrm{CH}_{3} \mathrm{CN}$ solution, proven to be the dinickel complex by $\mathrm{X}$-ray structure and ${ }^{+}$ESI-MS analyses.

\subsection{Synthesis of $\mathrm{ClMW}(\mathrm{CO})_{5}$}

The $\mathrm{W}(\mathrm{CO})_{5}$ (solv) was generated in situ by $\mathrm{W}(\mathrm{CO})_{6}$ in THF under UV light, after which the golden yellow solution was directly transferred to a white suspension of $\mathrm{XMN}_{2} \mathrm{~S}_{2}(\mathrm{M}=\mathrm{GaCl} / \mathrm{InCl})$ in THF. Then, the mixture was stirred at room temperature and monitored by FTIR. After several hours, the color changed to a clear brown-orange and without further $v(\mathrm{CO})$ change. IR $\left(\mathrm{cm}^{-1}\right): \mathrm{ClGaN}_{2} \mathrm{~S}_{2} \mathrm{~W}(\mathrm{CO})_{5}$, 
$v(\mathrm{CO})$ 2068(w), 1929(s), 1889(m); $\mathrm{ClInN}_{2} \mathrm{~S}_{2} \mathrm{~W}(\mathrm{CO})_{5}, \mathrm{v}(\mathrm{CO})$ 2068(w), 1929(s), 1892(m). - ${ }^{-}$ESI-Mass: [ClInN $\mathrm{S}_{2} \mathrm{~W}(\mathrm{CO})_{5}+\mathrm{Cl}^{+}\left(\mathrm{C}_{14} \mathrm{H}_{18} \mathrm{ClGaN}_{2} \mathrm{O}_{5} \mathrm{~S}_{2} \mathrm{~W}\right)$ Calculated 680.88; Found: 680.92; [ClInN $\mathrm{S}_{2} \mathrm{~W}(\mathrm{CO})_{5}$ $+\mathrm{Cl}]^{+}\left(\mathrm{C}_{14} \mathrm{H}_{18} \mathrm{ClInN} \mathrm{N}_{2} \mathrm{O}_{5} \mathrm{~S}_{2} \mathrm{~W}\right)$ Calculated 726.86; Found: 726.94 .

\section{Conclusions}

Through this study, we have demonstrated that the main group metals $\mathrm{Al}, \mathrm{Ga}$, and In can bind within the tetradentate chelating pocket of an $\mathrm{N}_{2} \mathrm{~S}_{2}$ ligand, yielding square pyramidal complexes. The $\mathrm{M}^{\mathrm{III}}$ sits above the $\mathrm{N}_{2} \mathrm{~S}_{2}$ plane and each is capped with an additional ligand, $\mathrm{CH}_{3}{ }^{-}$in the case of $\mathrm{Al}^{\mathrm{III}}$ and $\mathrm{Cl}^{-}$for $\mathrm{Ga}^{\mathrm{III}}$ and $\mathrm{In}^{\mathrm{III}}$. Known to be tunable via the $\mathrm{N}$ to $\mathrm{N}$ and $\mathrm{N}$ to $\mathrm{S}$ linkers of the $\mathrm{MN}_{2} \mathrm{~S}_{2}$ metallodithiolates, our account extends the range of metals that define the nucleophilicity of the sulfurs in metallodithiolates as aggregating sites for exogeneous metals. The system demonstrates that the $\mathrm{XMN}_{2} \mathrm{~S}_{2}$ complexes bind to $\mathrm{W}(\mathrm{CO})_{5}$ and $\mathrm{W}(\mathrm{CO})_{4}$, forming isolable complexes, one of which was subjected to XRD analysis. Solution $v(\mathrm{CO})$ IR spectral values permit comparisons of donor ability with transition metals such as $\mathrm{NiN}_{2} \mathrm{~S}_{2}$ where the $\mathrm{Ni}_{\mathrm{d} \pi}-\mathrm{S}_{\mathrm{p} \pi}$ antibonding interaction leads to greater donor ability. In addition, compared with $\mathrm{NiN}_{2} \mathrm{~S}_{2}$, the $\mathrm{XM}^{\mathrm{III}} \mathrm{N}_{2} \mathrm{~S}_{2}$ complexes are less stable and can readily convert to $\mathrm{NiN}_{2} \mathrm{~S}_{2}$ on exposure to $\mathrm{Ni}^{\mathrm{II}}$ when made available as a salt or when bound by diphos, bis-diphenylphosphino ethane. Such fundamental studies are useful for extending main group coordination chemistry.

Supplementary Materials: The following are available online at http://www.mdpi.com/2304-6740/7/9/115/s1: ${ }^{1} \mathrm{H}-\mathrm{NMR}$ and ${ }^{13} \mathrm{C}-\mathrm{NMR}$ Spectra (Figures S1-S3); Mass Spectra (Figures S4-S12); X-ray Crystal Structures (Figures S13-S16, Table S1-S4); FTIR Spectra of CInn ${ }_{2} \mathrm{~S}_{2} \cdot \mathrm{W}(\mathrm{CO})_{4}$ (Figure S17); The deviations of Nitrogen and Sulfur atoms from $\mathrm{N}_{2} \mathrm{~S}_{2}$ plane (Figure S18); The ratio of $\mathrm{M}-\mathrm{N} / \mathrm{M}-\mathrm{S}$ in $\mathrm{XMN}_{2} \mathrm{~S}_{2}$ (Table S5); Different $v(\mathrm{CO}$ ) values in $\mathrm{MW}(\mathrm{CO})_{4}$ comparison (Table S6).

Author Contributions: M.Y.D. and X.Y. designed the project. X.Y. synthesized and characterized the complexes. All authors contributed to the writing and editing the manuscript.

Funding: This work was financially supported by the National Science Foundation (CHE-1266097, CHE-1665258) and the Robert A. Welch Foundation (A-0924).

Acknowledgments: We thank Trung Le and Xiaogao Meng for their help in solving the crystal structure. We acknowledge the work of Michelle L. Hatley, M.S., TAMU, who initiated the gallium synthesis.

Conflicts of Interest: The authors declare no conflict of interest.

\section{References}

1. Busch, D.H.; Jicha, D.C.; Thompson, M.C.; Wrathall, J.W.; Blinn, E. Reactions of Coordinated Ligands. VIII. The Reactions of Alkyl Halides with Mercapto Groups in Transition Metal Complexes of Mercaptoamines. J. Am. Chem. Soc. 1964, 86, 3642-3650. [CrossRef]

2. Can, M.; Armstrong, F.A.; Ragsdale, S.W. Structure, Function, and Mechanism of the Nickel Metalloenzymes, CO Dehydrogenase, and Acetyl-CoA Synthase. Chem. Rev. 2014, 114, 4149-4174. [CrossRef] [PubMed]

3. Doukov, T.I.; Blasiak, L.C.; Seravalli, J.; Ragsdale, S.W.; Drennan, C.L. Xenon in and at the End of the Tunnel of Bifunctional Carbon Monoxide Dehydrogenase/Acetyl-CoA Synthase. Biochemistry 2008, 47, 3474-3483. [CrossRef] [PubMed]

4. Smee, J.J.; Miller, M.L.; Grapperhaus, C.A.; Reibenspies, J.H.; Darensbourg, M.Y. Subtle Bite-Angle Influences on $\mathrm{N}_{2} \mathrm{~S}_{2} \mathrm{Ni}$ Complexes. Inorg. Chem. 2001, 40, 3601-3605. [CrossRef]

5. Mills, D.K.; Reibenspies, J.H.; Darensbourg, M.Y. Sterically protected nickel(II) in a $\mathrm{N}_{2} \mathrm{~S}_{2}$ donor environment: 1,5-bis(mercaptoethyl)-1,5-diazacyclooctane and its methylated derivative. Inorg. Chem. 1990, 29, 4364-4366. [CrossRef]

6. Zhao, T.; Ghosh, P.; Martinez, Z.; Liu, X.; Meng, X.; Darensbourg, M.Y. Discrete Air-Stable Nickel(II)-Palladium(II) Complexes as Catalysts for Suzuki-Miyaura Reactions. Organometallics 2017, 36, 1822-1827. [CrossRef]

7. Denny, J.A.; Darensbourg, M.Y. Metallodithiolates as Ligands in Coordination, Bioinorganic, and Organometallic Chemistry. Chem. Rev. 2015, 115, 5248-5273. [CrossRef] 
8. Yang, Z.; Yi, Y.; Zhong, M.; De, S.; Mondal, T.; Koley, D.; Ma, X.; Zhang, D.; Roesky, H.W. Addition Reactions of $\mathrm{Me}_{3} \mathrm{SiCN}$ with Aldehydes Catalyzed by Aluminum Complexes Containing in Their Coordination Sphere O, S, and N Ligands. Chem. Eur. J. 2016, 22, 6932-6938. [CrossRef]

9. Chu, T.; Vyboishchikov, S.F.; Gabidullin, B.; Nikonov, G.I. Oxidative Cleavage of $\mathrm{C}=\mathrm{S}$ and $\mathrm{P}=\mathrm{S}$ Bonds at an $\mathrm{Al}^{\mathrm{I}}$ Center: Preparation of Terminally Bound Aluminium Sulfides. Angew. Chem. Int. Ed. 2016, 55, 13306-13311. [CrossRef]

10. Kim, S.H.; Han, S.Y.; Kim, J.H.; Kang, Y.Y.; Lee, J.; Kim, Y. Monomeric or Dimeric Aluminium Complexes as Catalysts for Cycloaddition between $\mathrm{CO}_{2}$ and Epoxides. Eur. J. Inorg. Chem. 2015, 13, 2323-2329. [CrossRef]

11. Darensbourg, D.J.; Billodeaux, D.R. Aluminum Salen Complexes and Tetrabutylammonium Salts: A Binary Catalytic System for Production of Polycarbonates from $\mathrm{CO}_{2}$ and Cyclohexene Oxide. Inorg. Chem. 2005, 44, 1433-1442. [CrossRef] [PubMed]

12. Alam, I.S.; Arrowsmith, R.L.; Cortezon-Tamarit, F.; Twyman, F.; Kociok-Köhn, G.; Botchway, S.W.; Dilworth, J.R.; Carroll, L.; Aboagye, E.O.; Pascu, S.I. Microwave Gallium-68 Radiochemistry for Kinetically Stable bis(thiosemicarbazone) Complexes: Structural Investigations and Cellular Uptake under Hypoxia. Dalton Trans. 2015, 45, 144-155. [CrossRef] [PubMed]

13. Zhang, N.; Tai, Y.; Li, M.; Ma, P.; Zhao, J.; Niu, J. Main Group Bismuth(III), Gallium(III) and Diorganotin(IV) Complexes derived from bis(2-acetylpyrazine) thiocarbonohydrazone: Synthesis, Crystal Structures and Biological Evaluation. Dalton Trans. 2014, 43, 5182-5189. [CrossRef] [PubMed]

14. Zhang, W.; Dodonov, V.A.; Chen, W.; Zhao, Y.; Skatova, A.A.; Fedushkin, I.L.; Roesky, P.W.; Wu, B.; Yang, X.J. Cycloaddition versus Cleavage of the $\mathrm{C}=\mathrm{S}$ Bond of Isothiocyanates Promoted by Digallane Compounds with Noninnocent $\alpha$-Diimine Ligands. Chem. Eur. J. 2018, 24, 14994-15002. [CrossRef] [PubMed]

15. Tai, Y.; Ji, Y.; Lu, Y.; Li, M.; Wu, Y.; Han, Q. Cadmium(II) and Indium(III) Complexes Derived from 2-benzoylpyridine N(4)-cyclohexylthiosemicarbazone: Synthesis, Crystal Structures, Spectroscopic Characterization and Cytotoxicity. Synth. Met. 2016, 219, 109-114. [CrossRef]

16. Arrowsmith, R.L.; Waghorn, P.A.; Jones, M.W.; Bauman, A.; Brayshaw, S.K.; Hu, Z.; Kociok-Köhn, G.; Mindt, T.L.; Tyrrell, R.M.; Botchway, S.W.; et al. Fluorescent Gallium and Indium bis(thiosemicarbazonates) and Their Radiolabelled Analogues: Synthesis, Structures and Cellular Confocal Fluorescence Imaging Investigations. Dalton Trans. 2011, 2011. 40, 6238-6252. [CrossRef]

17. Anderson, T.S.; Briand, G.G.; Brüning, R.; Decken, A.; Margeson, M.J.; Pickard, H.M.; Trevors, E.E. Synthesis, Characterization and Reactivity of (dithiolato)Indium Complexes. Polyhedron 2017, 135, 101-108. [CrossRef]

18. Wadas, T.J.; Wong, E.H.; Weisman, G.R.; Anderson, C.J. Coordinating Radiometals of Copper, Gallium, Indium, Yttrium, and Zirconium for PET and SPECT Imaging of Disease. Chem. Rev. 2010, 110, 2858-2902. [CrossRef]

19. Addison, A.W.; Rao, T.N.; Reedijk, J.; Jacobus, V.R.; Verschoor, G.C. Synthesis, Structure, and Spectroscopic Properties of Copper(II) Compounds Containing Nitrogen-Sulphur Donor Ligands; the Crystal and Molecular Structure of aqua [1,7-bis( $N$-methylbenzimidazol-2'-yl)-2,6-dithiaheptane]Copper(II) Perchlorate. J. Chem. Soc. Dalton Trans. 1984, 7, 1349-1356. [CrossRef]

20. Hess, J.; Conder, H.L.; Green, K.N.; Darensbourg, M.Y. Electronic Effects of $\left(\mathrm{N}_{2} \mathrm{~S}_{2}\right) \mathrm{M}(\mathrm{NO})$ Complexes $(\mathrm{M}=\mathrm{Fe}$, Co) as Metallodithiolate Ligands. Inorg. Chem. 2008, 47, 2056-2063. [CrossRef]

21. Jenkins, R.; Pinder, T.A.; Hatley, M.L.; Reibenspies, J.H.; Darensbourg, M.Y. Tetradentate $\mathrm{N}_{2} \mathrm{~S}_{2}$ Vanadyl(IV) Coordination Complexes: Synthesis, Characterization, and Reactivity Studies. Inorg. Chem. 2011, 50, 1849-1855. [CrossRef] [PubMed]

22. Darensbourg, D.J.; Kump, R.L. A Convenient Synthesis of cis-Mo(CO) ${ }_{4} \mathrm{~L}_{2}$ Derivatives (L = Group 5A Ligand) and a Qualitative Study of Their Thermal Reactivity toward Ligand Dissociation. Inorg. Chem. 1978, 17, 2680-2682. [CrossRef]

23. Rampersad, M.V.; Jeffery, S.P.; Golden, M.L.; Lee, J.; Reibenspies, J.H.; Darensbourg, D.J.; Darensbourg, M.Y. Characterization of Steric and Electronic Properties of $\mathrm{NiN}_{2} \mathrm{~S}_{2}$ Complexes as S-donor Metallodithiolate Ligands. J. Am. Chem. Soc. 2005, 127, 17323-17334. [CrossRef] [PubMed]

(C) 2019 by the authors. Licensee MDPI, Basel, Switzerland. This article is an open access article distributed under the terms and conditions of the Creative Commons Attribution (CC BY) license (http://creativecommons.org/licenses/by/4.0/). 